\title{
Carcinoma of the Eyelid cNO TNM Finding v7
}

National Cancer Institute

\section{Source}

National Cancer Institute. Carcinoma of the Eyelid cNO TNM Finding v7. NCI Thesaurus. Code C88578.

Carcinoma of the eyelid with no regional lymph node metastasis, based upon clinical evaluation or imaging. (from AJCC 7th Ed.) 